\title{
POSREDUJUĆA ULOGA EMOCIONALNE REGULACIJE U ODNOSU RODITELJSKOGA PONAŠANJA I PRILAGODBE MLAĐIH ADOLESCENATA
}

Ivana MACUKA

Sveučilište u Zadru, Zadar

Sanja SMOJVER-AŽıć

Filozofski fakultet, Rijeka

Irena BURIĆ

Sveučilište u Zadru, Zadar

UDK: 159.942-053.6:159.942-055.52

Izvorni znanstveni rad

Primlieno: 14. 4. 2011.

Cilj ovog rada je bio ispitati vezu između roditeljskoga ponašanja obaju roditelja te emocionalne regulacije i internaliziranih $\mathrm{i}$ eksternaliziranih problema mlađih adolescenata. Poseban naglasak $u$ istraživanju bio je na ispitivanju posredujuće uloge emocionalne regulacije $u$ odnosu roditeljskoga ponašanja $i$ prilagodbe mlađih adolescenata. Istraživanje je provedeno na uzorku od 261 učenika sedmih i osmih razreda osnovne škole. Provedene su dvije analize traga u kojima su zasebno razmatrani izravni i posredni učinci (posredstvom emocionalne regulacije) majčina i očeva roditeljskoga ponašanja na zastupljenost internaliziranih i eksternaliziranih problema. Dobiveni rezultati pokazuju da emocionalna regulacija potpuno objašnjava povezanost između internaliziranih problema i dječje percepcije majčina prihvaćanja, očeva odbacivanja i očeve kontrole, a djelomično i povezanost između internaliziranih problema i očeva prihvaćanja. Dječja percepcija majčine kontrole i očeva prihvaćanja imala je izravne učinke na internalizirane probleme, a eksternalizirani problemi bili su izravno povezani s percepcijom majčine kontrole te očeva i majčina prihvaćanja.

Ključne riječi: emocionalna regulacija, internalizirani i eksternalizirani problemi, roditeljsko ponašanje, rana adolescencija 
Iako je tema uloge obitelji u prilagodbi djece i adolescenata česta u empirijskim istraživanjima, nedovoljna pažnja posvećena je mehanizmima kojima obiteljsko funkcioniranje utječe na psihosocijalnu prilagodbu djece. Učenje reguliranja emocionalnih reakcija i povezanih ponašanja na socijalno poželjne i adaptivne načine predstavlja bitnu komponentu uspješnog razvoja djece (Eisenberg i sur., 2002.; Cole i sur., 2004.). Istraživanja na području razvojne psihopatologije ističu važnost emocionalne regulacije $u$ psihosocijalnoj prilagodbi djece te povezuju poteškoće $\mathrm{u}$ reguliranju negativnih emocija, kao što su ljutnja i tuga, s emocionalnim i ponašajnim problemima (Cicchetti i sur., 1995.; Silk i sur., 2003.). Istraživanja konstrukta emocionalne regulacije koja predstavlja sposobnost pojedinca da upravlja i usmjerava vlastite emocionalne reakcije tek su se nedavno počela u većoj mjeri provoditi (Cole i sur., 2004.). Individualne razlike $u$ vještinama emocionalne regulacije mogu biti izvor ranjivosti ili otpora u psihosocijalnoj prilagodbi, odnosno za dobru prilagodbu djeteta važno je da dijete reagira prikladnim emocijama i da ima mehanizme regulacije koji će mu omogućiti učinkovito upravljanje emocijama kako bi postiglo svoje ciljeve i uskladilo se s okolinom. Proučavanje uloge emocionalne regulacije nudi nove perspektive u razumijevanju prilagodbe djece i adolescenata te se u novije vrijeme sve češće primjenjuje znanje o emocionalnoj regulaciji u proučavanju psihosocijalnih problema djece i adolescenata.

Okosnicu ovog istraživanja čini Trostruki model utjecaja obitelji na dječju emocionalnu regulaciju i prilagodbu autorice Morris i suradnika (2007.), koji pruža sveobuhvatan okvir za analiziranje rizičnih i zaštitnih osobnih i obiteljskih činitelja prilagodbe djece i adolescenata. Na temelju ovoga modela dječja emocionalna regulacija i prilagodba višestruko su determinirane varijablama iz tri domene: individualnim karakteristikama djeteta, individualnim karakteristikama roditelja i obiteljskim faktorima (među koje ulazi roditeljsko ponašanje očeva i majki). Poseban naglasak $u$ ovom modelu stavljen je na procese emocionalne regulacije, za koje se pretpostavlja da predstavljaju važan mehanizam kojim osobne karakteristike djeteta i karakteristike djetetove okoline, posebno obitelji, ostvaruju utjecaj na djetetovu prilagodbu. Autori modela ističu da iako postoje izravni učinci obiteljskoga konteksta na prilagodbu djece (npr. internalizacija, eksternalizacija, socijalna kompetencija), velik dio utjecaja obiteljskoga konteksta na psihosocijalni razvoj djece odvija se kroz utjecaj obitelji na emocionalnu regulaciju djece, pa je stoga uloga emocionalne regulacije u ovom modelu medijacijska. Postoje i empirijski dokazi za ovakvo gledište, primjerice Eisenberg i suradnici (2001.b) potvrđuju da su efekti roditeljskoga ponašanja na eksternali- 
DRUŠ. ISTRAŽ. ZAGREB GOD. 21 (2012), BR. $2(116)$

STR. $383-403$

MACUKA, I., SMOJVER-AŽIĆ, S., BURIĆ, I. POSREDDUUJUCA zirane probleme djece indirektni kroz dječju emocionalnu regulaciju.

Emocionalna je regulacija pojam koji se upotrebljava na razne načine. Neki ga istraživači rabe kako bi upozorili na individualne razlike $\mathrm{u}$ intenzitetu, frekvenciji i trajanju emocija, a neki pojam emocionalna regulacija upotrebljavaju kako bi uputili na ravnotežu emocija koje neki pojedinac pokazuje. Gross (1998.) definira emocionalnu regulaciju kao procese kojima pojedinci utječu na to koje će emocije doživjeti, kada će ih doživjeti i kako će ih izraziti. On smatra kako prepoznavanje i razumijevanje vlastitih emocionalnih iskustava čini osnovu za regulaciju koja uključuje i procese nadgledanja, evaluiranja i modificiranja. Thompson (1994.) navodi da se emocionalna regulacija sastoji od ekstrinzičnih i intrinzičnih procesa odgovornih za nadgledanje, evaluiranje i modificiranje emocionalnih reakcija, osobito obilježja njihova intenziteta i trajanja, kako bi pojedinac postigao svoje ciljeve. Općenito, može se zaključiti kako emocionalna regulacija pomaže osobi da uskladi izražavanje emocija sa zahtjevima okoline (regulacija ponašanja) i da se zaštiti od neugodnih emocija, da ih obuzda i usmjeri tako da ne ometaju njegovo funkcioniranje (regulacija emocionalnoga doživljaja) (Cudina-Obradović i Obradović, 2006.). Mjerenju emocionalne regulacije najčešće se pristupa primjenom skala samoprocjene, jer omogućavaju uvid u subjektivne procese osobe. $\mathrm{S}$ obzirom na to da roditelji kao procjenjivači dječje emocionalne regulacije mogu biti skloni određenim pristranostima, bilo zbog želje da prezentiraju dijete $\mathrm{u}$ pozitivnijem svijetlu ili zbog toga što nisu dobro upoznati sa strategijama emocionalne regulacije koje djeca rabe, kod adolescenata je primjereno primijeniti mjeru samoprocjene. Odnosno, adolescencija je ipak razdoblje u kojem se povećava kognitivna kompleksnost, pa su za adolescente mjere samoprocjene razvojno prikladne i preporučljive. Važno je istaknuti da su mnogi okolinski čimbenici uključeni u proces dječjeg učenja procjenjivanja vlastitih osjećaja (i sebe kao emocionalnoga bića) te stjecanja specifičnih vještina potrebnih za upravljanje vlastitim osjećajima. Morris i suradnici (2007.) navode da je utjecaj obitelji na emocionalnu regulaciju djece jedan od načina na koji odnosi unutar obiteljskoga konteksta utječu na psihosocijalni razvoj djece. Unatoč više desetljeća istraživanja važnosti obiteljskoga konteksta u razvoju i prilagodbi djece, tek nedavno se istraživanja usmjeravaju na utjecaj obiteljskih čimbenika na razvoj sposobnosti emocionalne regulacije (Eisenberg i sur., 1998.; Eisenberg i sur., 2001.a, 2001.b).

Kada je riječ o problemima prilagodbe, veći broj pojedinih problema može se poredati na dimenziji internalizacije-eksternalizacije dječjih problema. Depresivni poremećaji vrlo 
DRUŠ. ISTRAŽ. ZAGREB GOD. 21 (2012)

BR. $2(116)$

STR. 383-403

MACUKA, I., SMOJVER-AŽIIĆ, S., BURIĆ, I. POSREDUJUĆA.. su rijetki u predškolskoj dobi i bez spolnih razlika u incidenciji, ali u adolescenciji postoji izrazito povećanje učestalosti, koje je za djevojčice dvostruko brže nego za dječake. U dobi od 16 godina djevojčice imaju dvaput veću vjerojatnost razvoja depresivne simptomatologije od dječaka (Tram i Cole, 2006.). Za sve dobne skupine od školske dobi do adolescencije dominirajući afekt je tuga, što upućuje na to da su potištenost, obeshrabrenost i osamljenost središnja obilježja kod depresivnih doživljaja. Kad je riječ o anksioznosti, i ona se s dobi povećava, pa djevojčice u većoj mjeri nego dječaci pokazuju pojedinačne simptome anksioznosti (Achenbach i sur, 2008.). Anksiozni simptomi ulaze među najčešće probleme dječje i adolescentne dobi, iako se njezini simptomi mijenjanju s dobi, pa su u djetinjstvu češći problemi separacije, a u adolescenciji izrazita zabrinutost i komorbidnost s depresivnim simptomima. Za eksternalizirane probleme karakteristično je da dijete iznosi svoj problem kroz odnos s društvom te pokazuje npr. agresivno i delinkventno ponašanje. Eksternalizirani problemi tradicionalno se konceptualiziraju kao problemi ponašanja i kognicije, ali ne i afekta, ali su usko povezani i s emocionalnim procesima i odražavaju deficite $u$ emocionalnoj regulaciji. Probleme eksternaliziranoga tipa često određuje ljutnja, neprijateljstvo, nepoštivanje socijalnih vrijednosti, koje se očituje u ponašanjima kao što su krađa i laganje, otimanje. Prevalencija agresivnoga ponašanja procjenjuje se u rasponu od 4 do $10 \%$ opće populacije, ovisno o strogosti upotrijebljenih kriterija, a što se tiče spolnih razlika, agresivno ponašanje češće je kod dječaka nego kod djevojčica (Archer, 2004.). U istraživanjima psihosocijalnih dječjih problema preporučuje se upotreba više nezavisnih mjera problema (primjerice od djece i roditelja) da bi se dobili valjaniji podaci. Međutim, za adolescente se smatra da predstavljaju najbolji izvor podataka o vlastitu ponašanju i doživljavanju, što potvrđuju i niske povezanosti između samoprocjena adolescenata i procjena drugih (roditelja) (Macuka, 2011.).

$\mathrm{U}$ ranoj adolescenciji, zbog intenzivnih promjena $\mathrm{u}$ raznim aspektima funkcioniranja, postoji povećan rizik za pojavu problema internaliziranoga i eksternaliziranoga tipa, u osnovi koje može biti izražena negativna emocionalnost i poteškoće u reguliranju negativnih emocija. Na području istraživanja prilagodbe adolescenata istraživači često nastoje ispitati promjene vezane $u z$ tranziciju $u$ adolescenciju, $u$ nastojanju da se utvrde mehanizmi odgovorni za često ubrzanje problema u psihosocijalnoj prilagodbi na prijelazu iz djetinjstva $u$ adolescenciju. Tako je utvrđeno da je jedna od značajnih promjena karakteristična za adolescenciju povećana učestalost i intenzitet negativnih emocija, koje mogu prethoditi pro- 
DRUŠ. ISTRAŽ. ZAGREB GOD. 21 (2012), BR. 2 (116)

STR. $383-403$

MACUKA, I., SMOJVER-AŽIĆ, S., BURIĆ, I. POSREDUUJUĆA. blemima. Individualnim razlikama u emocionalnoj regulaciji, osim temperamenta, tj. urođenih tendencija djeteta prema izražavanju i doživljavanju nekih vrsta emocija, mogu pridonijeti i obiteljski čimbenici. Razvojne promjene $u$ adolescenciji potiču vještine nužne za stjecanje veće nezavisnosti od obitelji i uspostavljanja razvojno važnih vršnjačkih i romantičnih odnosa, ali i stvaraju veću osjetljivost na emocionalne probleme i probleme u ponašanju (Steinberg, 2005.).

Roditelji utječu na emocionalnu regulaciju djece svojim specifičnim reakcijama na dječje negativne i pozitivne emocije (Gottman i sur., 1996.). Pritom se oblici roditeljskoga ponašanja mogu promatrati kao predisponirajući faktori ili izvori ranjivosti u djetetovu razvoju, ali i kao zaštitni faktori. Istraživanja na području roditeljstva konzistentno pokazuju kako općenito bolju prilagodbu imaju djeca koja su uspostavila sigurnu privrženost s roditeljima, koja imaju roditelje koji su emocionalno topli i umjereno kontrolirajući te potiču i prihvaćaju dijete (Cummings i sur., 2000.). Kada se promatraju efekti roditeljskoga ponašanja na dječji razvoj, najčešće se u istraživanjima navode dvije temeljne dimenzije roditeljskoga ponašanja u svim razvojnim razdobljima: emocionalnost i kontrola (Darling i Steinberg, 1993.; Martin i Colbert, 1997.; Cummings i sur., 2000.). Dimenzija emocionalnosti naziva se često podrškom, toplinom, osjetljivošću, prihvaćanjem ili njegovanjem. Kako je riječ o bipolarnoj dimenziji roditeljskoga ponašanja, na jednom kraju ove dimenzije nalazi se emocionalna toplina i prihvaćanje djeteta, a na drugom kraju hladnoća, odbacivanje, udaljenost, neprijateljstvo prema djetetu. Karakteristično za ovu dimenziju roditeljstva jest da se ona odnosi na emocije koje roditelj doživljava i pokazuje u svojem odnosu s djetetom. Emocionalno topli roditelji prihvaćaju svoju djecu, pružaju im podršku, razumijevanje, brigu i pažnju, prijateljski su raspoloženi prema djetetu, nastoje vidjeti stvari iz njegove perspektive te poštuju njegove osjećaje, a od tehnika discipliniranja rabe objašnjenja, pohvale i ohrabrivanja. Emocionalno hladni roditelji zanemaruju svoje dijete, odbacuju ga, neprijateljski su raspoloženi prema njemu te općenito pokazuju malo pozitivnih emocija u kontaktu s djetetom. Djeca koja odrastaju uz roditelje koji im pružaju emocionalnu podršku često imaju manje problema u prilagodbi, veće sposobnosti regulacije vlastita ponašanja, izraženije prosocijalno ponašanje i visoko samopoštovanje. $S$ druge strane, manjak prihvaćanja i podrške od strane roditelja povezan je s neadaptivnim razvojnim ishodima kod djece, poput povlačenja, agresije i poremećaja pažnje (Cummings i sur., 2000.). Kontrola djetetova ponašanja od strane roditelja uključuje i psihološko i bihevioralno kontroliranje (Darling i Steinberg, 1993.; Cummings 
DRUŠ. ISTRAŽ. ZAGREB GOD. 21 (2012)

BR. $2(116)$

STR. 383-403

MACUKA, I., SMOJVER-AŽIIĆ, S., BURIĆ, I. POSREDUJUĆA.. i sur., 2000.). Psihološkom kontrolom roditelji nastoje pratiti djetetove unutarnje doživljaje, emocije i misli te primjenjuju niz odgojnih postupaka koji ne pogoduju razvoju djetetove psihološke nezavisnosti, samostalnosti i individuacije. Psihološka kontrola često je posljedica prikrivene agresije i očituje se kao manipuliranje djetetovim ponašanjem kritiziranjem, stvaranjem osjećaja krivnje te omalovažavanjem djetetovih osjećaja. Upravo ova dimenzija roditeljskoga ponašanja osobito je važna $u$ adolescenciji, kada dijete intenzivno teži nezavisnosti od roditelja i kada bi roditelji trebali poticati psihološku nezavisnost svojega djeteta. Za razliku od psihološke kontrole, bihevioralna kontrola uključuje postavljanje pravila ponašanja i dopuštenih granica, kako bi se izbjeglo nepoželjno ponašanje kod djece.

Riley i Steinberg (2004.) naglašavaju kako se roditeljski nadzor mijenja $\mathrm{u}$ funkciji djetetove dobi, pa se $\mathrm{u}$ adolescenciji djelotvoran nadzor djetetova ponašanja postiže razgovorom i raspravom, a adolescenti sve više preuzimaju kontrolu nad svojim ponašanjem i dobrovoljno izvještavaju roditelje o svojim aktivnostima. U suprotnom, kada nadzor od strane roditelja nije usklađen s razvojem djeteta te se roditelji i dalje koriste izravnim oblicima kontrole, mogu nastati određeni problemi u komunikaciji roditelja i djeteta i prilagodbi djeteta. Istraživanja raznih autora pokazuju kako je psihološka kontrola od strane roditelja konzistentni prediktor internaliziranih simptoma (depresije, poremećaja hranjenja, usamljenosti), eksternaliziranih problema (delinkvencije), lošijega školskog uspjeha, uporabe droge i somatskih simptoma (Pettit i sur., 2001.; Stolz i sur., 2005.; Caron i sur., 2006.; Macuka, 2007.b). Također, istraživanja pokazuju kako je roditeljsko prihvaćanje, podrška i suosjećanje povezano s razvojem uspješne emocionalne regulacije kod djece (Kliewer i sur., 1996.) te kako je majčina suosjećajnost i responzivnost povezana s nižim razinama opaženih negativnih emocija kod djece (Eisenberg i sur., 1999.). $\mathrm{S}$ druge strane, negativno roditeljsko ponašanje, koje uključuje neprijateljstvo, psihološku kontrolu, manjak osjetljivosti na djetetove potrebe, povezano je s neadekvatnom emocionalnom regulacijom (Calkins i sur., 1998.). Problemi u reguliranju emocija kod djece mogu nastati zbog izostanka roditeljske podrške, odsutnosti pozitivnih emocija, krute discipline, psihološke kontrole djetetova ponašanja te nekonzistentnosti u odgojnim metodama (Shipman i Zeman, 2001.). Zaključno, rezultati navedenih istraživanja općenito pokazuju da dimenzije roditeljskoga ponašanja, emocionalnost i kontrola imaju važan utjecaj na dječji razvoj i prilagodbu. U dosadašnjim istraživanjima utvrđeni su izravni učinci obiteljskoga konteksta na dječju prilagodbu (Barber, 1996.; Herman i sur., 1997.; Pettit i sur., 2001.; Shipman i Zeman, 2001.; Stolz i sur., 2005.; 
DRUŠ. ISTRAŽ. ZAGREB GOD. 21 (2012), BR. $2(116)$

STR. 383-403

MACUKA, I., SMOJVER-AŽIĆ, S., BURIĆ, I. POSREDUUUUĆA.

\section{METODA}

\section{Ispitanici}

Caron i sur., 2006.; Macuka, 2007.b, Macuka, 2008.) te povezanost poteškoća u reguliranju negativnih emocija, kao što su ljutnja, strah i tuga, s emocionalnim i ponašajnim problemima (Cicchetti i sur., 1995.; Cole i sur., 2004.; Eisenberg i sur., 2005.). Međutim, iako ima mnogih istraživanja o odnosu roditeljskoga ponašanja i dječje psihosocijalne prilagodbe, malo se istraživanja usmjerilo na ispitivanje odnosa roditeljskoga ponašanja i emocionalne regulacije djece.

Cilj je ovog istraživanja provjeriti neke postavke modela autorice Morris i suradnika (2007.). Preciznije, s obzirom na relevantnost konstrukta emocionalne regulacije u dječjoj prilagodbi, u ovom istraživanju nastojat će se ispitati medijacijska uloga emocionalne regulacije u objašnjenju internaliziranih i eksternaliziranih problema mlađih adolescenata. Pritom se očekuje da roditeljsko ponašanje na dječju prilagodbu utječe i izravno i neizravno emocionalnom regulacijom. Iako se velik broj dosadašnjih istraživanja o efektima obiteljskih čimbenika na emocionalnu regulaciju djece usmjerio na proučavanje utjecaja roditeljskoga ponašanja majki usprkos važnosti i roditeljske uloge očeva (pregled istraživanja u Morris i sur., 2007.), u okviru ovog istraživanja usmjerit će se na ispitivanje zasebne uloge dječje percepcije roditeljskoga ponašanja majki i očeva u objašnjenju emocionalne regulacije i prilagodbe mlađih adolescenata. Prema modelu, očekuje se da će roditeljsko ponašanje majki i očeva biti povezano s djetetovim vještinama emocionalne regulacije i problemima prilagodbe internaliziranoga i eksternaliziranoga tipa. Ujedno se pretpostavlja da će vještine emocionalne regulacije objasniti dio povezanosti između zasebnoga roditeljskog ponašanja majki i očeva i prilagodbe djece. Pretpostavlja se da će djeca koja procjenjuju da im roditelji pružaju emocionalnu podršku bolje regulirati negativne emocije i imati manje problema internaliziranoga i eksternaliziranoga tipa. S druge strane, očekuju se negativni efekti odbacivanja od strane roditelja i povećane kontrole djetetova ponašanja na dječju emocionalnu regulaciju i prilagodbu.

Istraživanje je provedeno na uzorku od 261 učenika sedmih i osmih razreda osnovne škole iz Zadra. U ispitivanju je sudjelovalo 139 učenica i 122 učenika prosječne dobi od 13 godina $(\mathrm{M}=12,97, \mathrm{sd}=0,69)$. Ispitivanje je provedeno anonimno $\mathrm{i}$ grupno za vrijeme redovite nastave u školi, pošto su ravnatelj škole i roditelji dali suglasnost za sudjelovanje djeteta u ispitivanju te djeca dobrovoljno pristala sudjelovati u istraživanju. Redoslijed ispunjavanja upitnika rotiran je od ispitanika do 
ispitanika, kako bi se kontrolirao utjecaj redoslijeda njihove primjene na rezultate.

\section{Mjerni instrumenti}

Skala samoprocjene ponašanja mladih - YSR

Skala samoprocjene ponašanja mladih (YSR - Youth Self-Report, Achenbach i Rescorla, 2001.) upotrijebljena je za ispitivanje dječjih internaliziranih i eksternaliziranih problema. Djeca procjenjuju svoje ponašanje i doživljavanje na 112 čestica, koje čine 8 sindromnih skala: povučenost, anksioznost/depresivnost, tjelesne poteškoće, socijalni problemi, problemi mišljenja, problemi pažnje, kršenje pravila (delinkventno ponašanje) i agresivno ponašanje. Dimenziju internaliziranih problema čine skale koje se odnose na psihološke poteškoće usmjerene na pojedinca i pretjerano kontrolirajuća ponašanja, a to su skale povučenosti, anksioznosti/depresivnosti i tjelesnih poteškoća. Internalizirani problemi odnose se na depresivnost, anksioznost, somatske probleme i druge neugodnosti koje drugima ne moraju biti vidljive ni neugodne (primjer čestica: "povučen sam, nastojim se držati po strani", "nesretan sam, tužan ili potišten"). Dimenziju eksternaliziranih problema obuhvaćaju maladaptivna ponašanja u raznim situacijama, koja stvaraju probleme drugima u djetetovoj okolini, odnosno negativno djeluju na djetetovu okolinu. Ovamo se ubrajaju skale agresivnosti i skala kršenja pravila (delinkventnoga ponašanja) (primjer čestica: "kršim pravila kod kuće, u školi i drugdje", "često zadirkujem druge"). Na svaku od 112 čestica u upitniku se odgovara na skali od tri stupnja (0 - nije točno, 1 - ponekad ili djelomično točno i 2 - potpuno točno). $\mathrm{U}$ ovom istraživanju ispitana je prisutnost internaliziranih $\mathrm{i}$ eksternaliziranih skupina problema kod djece te su dobiveni zadovoljavajući koeficijenti pouzdanosti izraženi Cronbach-alphom za pojedine upotrijebljene skale. Za skalu internaliziranih problema koeficijent pouzdanosti na cijelom uzorku ispitanika iznosi 0,87 , a za skalu eksternaliziranih problema 0,90 .

\section{Upitnik emocionalne regulacije i kontrole}

Upitnikom emocionalne regulacije i kontrole (UERK, Takšić, 2003.) procjenjuje se učinak neugodnih emocija i raspoloženja na mišljenje, pamćenje i ponašanje pojedinca. Upitnik UERK sadrži 20 tvrdnji kojima je cilj procjena (negativnih) efekata emocija i raspoloženja na mišljenje, pamćenje i ponašanje, kao i sposobnost emocionalne kontrole (primjer čestica: "Kada sam lošeg raspoloženja, čak mi se i mali problem čini nesavladiv", "Kada me netko naljuti, odmah i vrlo burno reagiram"). Zadatak ispitanika jest da na skali Likertova tipa od 5 stupnjeva (1 - uopće ne, 2 - uglavnom ne, 3 - kako kada, 4 uglavnom da i 5 - potpuno) procijene koliko se pojedina tvrd- 
DRUŠ. ISTRAŽ. ZAGREB GOD. 21 (2012), BR. 2 (116),

STR. $383-403$

MACUKA, I., SMOJVER-AŽIĆ, S., BURIĆ, I. POSREDUUUJĆA. nja odnosi na njih. Radi lakše interpretacije, tvrdnje koje se odnose na emocionalnu regulaciju i kontrolu obrnuto su se bodovale $\mathrm{u}$ ovom istraživanju, tako da se postignuti viši rezultat odnosi na bolje upravljanje i kontrolu negativnih emocija. Dobiveni koeficijent unutarnje pouzdanosti tipa Cronbach-alpha UERK upitnika u ovom istraživanju iznosio je 0,88 .

\section{Skala percepcije roditeljskog ponašanja}

Skalom percepcije roditeljskog ponašanja - SPRP (Macuka, 2007.a) - ispituje se percepcija ponašanja roditelja od strane djece $i$ adolescenata na dimenziji emocionalnosti i kontrole. Skala SPRP-a sadrži 25 tvrdnji koje zahvaćaju temeljne dimenzije roditeljskoga ponašanja: emocionalnost (prihvaćanje i odbacivanje) i kontrolu. Emocionalnost uključuje 15 tvrdnji koje se odnose na emocije što ih roditelji izražavaju u odnosu s djetetom u raznim situacijama, a zasebno se boduje rezultat na podskali prihvaćanje, koja sadrži 7 tvrdnji (primjer čestica: "Pruža mi sigurnost", "Ohrabruje me da uspijem u drugim aktivnostima izvan škole") i podskali odbacivanje, koja sadrži 8 tvrdnji (primjer čestica: "Imam osjećaj kao da me ne primjećuje", "Ne pokazuje mi da me voli"). Podskala kontrola sadrži 10 tvrdnji koje opisuju kontrolu djetetova ponašanja, tj. postupke kojima se roditelji služe kako bi modificirali ponašanja i doživljavanje djeteta (primjer čestica: "Često me ucjenjuje ako se ne držim njegovih pravila ponašanja", "Stalno me ispituje"). Zadatak ispitanika jest da na skali od 3 stupnja (1 - netočno, 2 - djelomično točno, 3 - potpuno točno) za svaku česticu označi odgovor koji najbolje opisuje način na koji se njegova majka ili otac odnosi prema njemu. Svako dijete ispunjava dva ista oblika upitnika, jedan je za procjenu majčina, a jedan za procjenu očeva ponašanja prema njemu. Viši rezultat na pojedinoj podskali pokazuje da djeca procjenjuju više prihvaćanja, odbacivanja ili kontrole od roditelja. Utvrđena pouzdanost izražena Cronbach-alphom u ovom istraživanju za podskalu prihvaćanje iznosi 0,75 za procjenu majčina prihvaćanja, a 0,74 za procjenu očeva prihvaćanja, zatim 0,72 za procjenu majčina odbacivanja, a 0,73 za procjenu očeva odbacivanja. Za podskalu kontrola također su utvrđene zadovoljavajuće pouzdanosti, koje iznose 0,80 za procjenu majčine kontrole, a 0,77 za procjenu očeve kontrole.

\section{REZULTATI}

\section{Deskriptivni pokazatelii i korelacijske analize}

U Tablici 1 prikazani su koeficijenti bivarijatnih korelacija me- 


\begin{tabular}{|c|c|c|c|c|c|c|c|c|c|c|}
\hline Varijable: & 1 & 2 & 3 & 4 & 5 & 6 & 7 & 8 & 9 & 10 \\
\hline $1 \mathrm{spol}$ & 1,00 & & & & & & & & & \\
\hline 2 internalizirani problemi & $0,14^{*}$ & 1,00 & & & & & & & & \\
\hline 3 eksternalizirani problemi & $-0,17^{*}$ & $0,37^{*}$ & 1,00 & & & & & & & \\
\hline 4 emocionalna regulacija & 0,12 & $-0,43^{*}$ & $-0,32^{*}$ & 1,00 & & & & & & \\
\hline 5 prihvaćanje - majka & $0,19^{*}$ & $-0,15^{*}$ & $-0,36^{*}$ & 0,05 & 1,00 & & & & & \\
\hline 6 odbacivanje - majka & $-0,21^{*}$ & $0,33^{*}$ & $0,42^{*}$ & $-0,17^{*}$ & $-0,40^{*}$ & 1,00 & & & & \\
\hline 7 kontrola - majka & 0,12 & $0,37^{*}$ & $0,51^{*}$ & $-0,31^{*}$ & $-0,20^{*}$ & $0,56^{*}$ & 1,00 & & & \\
\hline 8 prihvaćanje - otac & 0,04 & $-0,22^{*}$ & $-0,29 *$ & $0,14^{*}$ & $0,69^{*}$ & $-0,23^{*}$ & $-0,21^{*}$ & 1,00 & & \\
\hline 9 odbacivanje - otac & $-0,21^{*}$ & $0,35^{*}$ & $0,40^{*}$ & $-0,17^{*}$ & $-0,32^{*}$ & $0,68^{*}$ & $0,42^{*}$ & $-0,41^{*}$ & 1,00 & \\
\hline 10 kontrola - otac & $-0,17^{*}$ & $0,27^{*}$ & $0,40^{*}$ & $-0,19^{*}$ & $-0,18^{*}$ & $0,42^{*}$ & $0,57^{*}$ & $-0,23^{*}$ & $0,56^{*}$ & 1,00 \\
\hline $\mathrm{M}$ & & 12,26 & 12,45 & 1,95 & 2,57 & 1,25 & 1,48 & 2,42 & 1,33 & 1,42 \\
\hline SD & & 7,64 & 8,24 & 0,62 & 0,38 & 0,31 & 0,34 & 0,38 & 0,32 & 0,31 \\
\hline
\end{tabular}

${ }^{*} \mathrm{p}<0,05$

i TABLICA 1

Tablica Pearsonovih koeficijenata korelacije između ispitivanih varijabli na cijelom uzorku ispitanika $(\mathrm{N}=261)$
Utvrđene korelacije pokazuju da djetetov spol značajno nisko korelira s internaliziranim i eksternaliziranim problemima, odnosno internalizirani problemi nešto su više zastupljeni kod djevojčica, a eksternalizirani problemi nešto više kod dječaka. Nadalje, dječaci i djevojčice različito doživljavaju odnos s roditeljima; dječaci percipiraju više odbacivanja i kontrole od oca te više odbacivanja i manje prihvaćanja od majke u odnosu na djevojčice. Utvrđene korelacije između dječjih problema i roditeljskoga ponašanja majki i očeva niske su do umjerene veličine. Dobiveni rezultati pokazuju da djeca koja procjenjuju da ih roditelji manje prihvaćaju te više odbacuju i kontroliraju imaju više razine internaliziranih i eksternaliziranih problema. Za varijablu emocionalna regulacija utvrđena je umjerena negativna povezanost $s$ dječjim problemima, više internaliziranih i eksternaliziranih problema imaju djeca koja slabije reguliraju vlastite negativne emocije. Nadalje, većina korelacija između emocionalne regulacije i roditeljskoga ponašanja majki i očeva niske je veličine, a dobiveni rezultati pokazuju da djeca koja procjenjuju da ih očevi više prihvaćaju bolje reguliraju svoje emocije, dok djeca koja procjenjuju da ih majke i očevi u većoj mjeri kontroliraju i odbacuju slabije reguliraju svoje negativne emocije.

\section{Analiza traga}

Provedbom analize traga ("path" analize) pomoću programa Mplus 5.21 (Muthen i Muthen, 2009.) ispitana je medijacijska uloga emocionalne regulacije između roditeljskoga ponašanja majki i očeva te dječje psihosocijalne prilagodbe. Pri tome je postavljena hipoteza o djelomičnoj medijaciji - roditeljsko ponašanje djeluje na dječju prilagodbu izravno, i neizravno utječući na njihove vještine emocionalne regulacije. Kako bi 
DRUŠ. ISTRAŽ. ZAGREB GOD. 21 (2012), BR. 2 (116),

STR. 383-403

MACUKA, I., SMOJVER-AŽIĆ, S., BURIĆ, I. POSREDUUUJĆA. se zadržala parsimoničnost, testirana su dva zasebna modela: A. model djelomične medijacije emocionalne regulacije u povezanosti majčina roditeljskog ponašanja i dječje prilagodbe, i B. model djelomične medijacije emocionalne regulacije u povezanosti očeva roditeljskog ponašanja i dječje prilagodbe. Iako je djetetov spol relevantan čimbenik u prilagodbi djeteta, zbog relativno maloga broja dječaka i djevojčica u čitavom uzorku, pa stoga i nepoželjnog omjera slobodnih parametara za procjenu i broja ispitanika, odlučeno je da se analiza traga provede na čitavom uzorku djece. U prilog tomu ide i utvrđivanje značajne, ali niske, korelacije između djetetova spola i problema internaliziranoga i eksternaliziranoga tipa. Kako su pretpostavljeni modeli djelomične medijacije upravo identificirani (tj. imaju nula stupnjeva slobode), što onemogućuje testiranje cjelokupnoga pristajanja modela podacima, $\mathrm{u}$ drugom koraku njihove provjere neznačajni parametri fiksirani su na nulu. Ovo je omogućilo identifikaciju modela (tj. pozitivan broj stupnjeva slobode) i izračunavanje indeksa njihova pristajanja s podacima.

Procjene parametara u modelu provedene su uz pomoć algoritma maksimalne vjerojatnosti $(\mathrm{ML}=$ maximum likelihood $)$. Podaci koji su nedostajali zamijenjeni su vrijednostima koje su procijenjene također uz pomoć ML algoritma, koji se ujedno smatra metodom izbora za tu svrhu (Brown, 2006.). Matrica sa sirovim podacima služila je kao ulazna matrica. Kao pokazatelji pristajanja modela s podacima primijenjene su sljedeće mjere: hi-kvadrat test, CFI (Comparative Fit Index), TLI (Tucker-Lewis Indeks), RMSEA (Root Mean Square Error of Approximation) i SRMR (Standardized Root Mean Square Residual). Vrijednosti CFI i TLI veće od 0,90, a vrijednosti RMSEA i SRMR manje od 0,10, upućuju na prihvatljivo slaganje modela, dok CFI i TLI iznad 0,95 te RMSEA i SRMR do 0,05 upućuju na dobro slaganje modela s podacima. Neznačajna $p$ vrijednost $\chi^{2}$ testa, kao i omjer hi-kvadrata i stupnjeva slobode manji od 2, indikatori su izvrsna slaganja modela s podacima (Hu i Bentler, 1999.). Indeksi slaganja testiranih modela prikazani su u Tablici 2, a njihovi grafički prikazi na Slikama 1 i 2 . Na temelju dobivenih vrijednosti slaganja, koje se uglavnom kreću u okviru referentnih vrijednosti, može se zaključiti da oba modela dobro pristaju podacima.

Model odnosa roditeljskoga ponašanja majki te emocionalne regulacije i dječjih internaliziranih i eksternaliziranih problema pokazuje izravne utjecaje dječje percepcije majčina prihvaćanja na dječje eksternalizirane probleme i izravne utjecaje majčine kontrole na dječje internalizirane i eksternalizirane probleme. Odnosno, djeca koja procjenjuju da ih majke manje prihvaćaju i češće kontroliraju imaju više eksternaliziranih problema, a djeca koja procjenjuju da ih majke više 
kontroliraju imaju više i internaliziranih problema. Prihvaćanje majke utječe na internalizirane probleme jedino posredno preko emocionalne regulacije, odnosno što je veće majčino prihvaćanje, djeca bolje reguliraju svoje emocije, što pridonosi manjoj zastupljenosti internaliziranih problema.

\begin{tabular}{|c|c|c|}
\hline $\begin{array}{l}\text { Kriteriji slaganja modela } \\
\text { (fit incides) }\end{array}$ & $\begin{array}{c}\text { A. MODEL } \\
\text { Roditeljsko ponašanje majki } \\
\text { Vrijednosti kriterija } \\
\text { slaganja modela }\end{array}$ & $\begin{array}{c}\text { B. MODEL } \\
\text { Roditeljsko ponašanje očeva } \\
\text { Vrijednosti kriterija } \\
\text { slaganja modela }\end{array}$ \\
\hline $\begin{array}{l}\chi^{2} / \mathrm{df} \\
\mathrm{p} \text { vrijednost }\end{array}$ & $\begin{array}{l}1,54 \\
0,20\end{array}$ & $\begin{array}{l}1,70 \\
0,13\end{array}$ \\
\hline $\begin{array}{l}\text { CFI } \\
\text { TLI } \\
\text { RMSEA } \\
\text { SRMR }\end{array}$ & $\begin{array}{l}0,975 \\
0,925 \\
0,054 \\
0,034\end{array}$ & $\begin{array}{l}0,946 \\
0,870 \\
0,061 \\
0,036\end{array}$ \\
\hline
\end{tabular}

( TABLICA 2

Kriteriii slaganja modela o medijacijskoi ulozi emocionalne regulacije $u$ odnosu roditeljskoga ponašanja majki i očeva i problema prilagodbe na uzorku diece $(\mathrm{N}=261)$

(1) SLIKA 1

Model odnosa roditeljskoga ponašanja majki te emocionalne regulacije i dječijh internaliziranih i eksternaliziranih problema
U prikazanom modelu, u kojem se ispitivao odnos roditeljskoga ponašanja očeva te emocionalne regulacije i dječjih internaliziranih i eksternaliziranih problema, mogu se uočiti značajni izravni utjecaji dječje percepcije očeva prihvaćanja na dječje internalizirane i eksternalizirane probleme. Djeca koja procjenjuju da ih otac manje prihvaća imaju više internaliziranih i eksternaliziranih problema. Nadalje, očevo prihvaćanje, osim izravnog utjecaja na dječje probleme, ima i indirektne efekte na internalizirane probleme preko emocionalne regulacije, odnosno djeca koja percipiraju veće prihvaćanje od oca bolje reguliraju svoje negativne emocije, što pridonosi manjoj zastupljenosti internaliziranih problema. Iz navedenih parametara prikazanih u modelu može se vidjeti kako dječja percepcija očeva odbacivanja i kontrole utječe na internalizirane probleme jedino posredno preko emocionalne regulacije. Djeca koja percipiraju veće očevo odbacivanje i kontrolu slabije reguliraju svoje negativne emocije, što pridonosi većoj zastupljenosti internaliziranih problema.

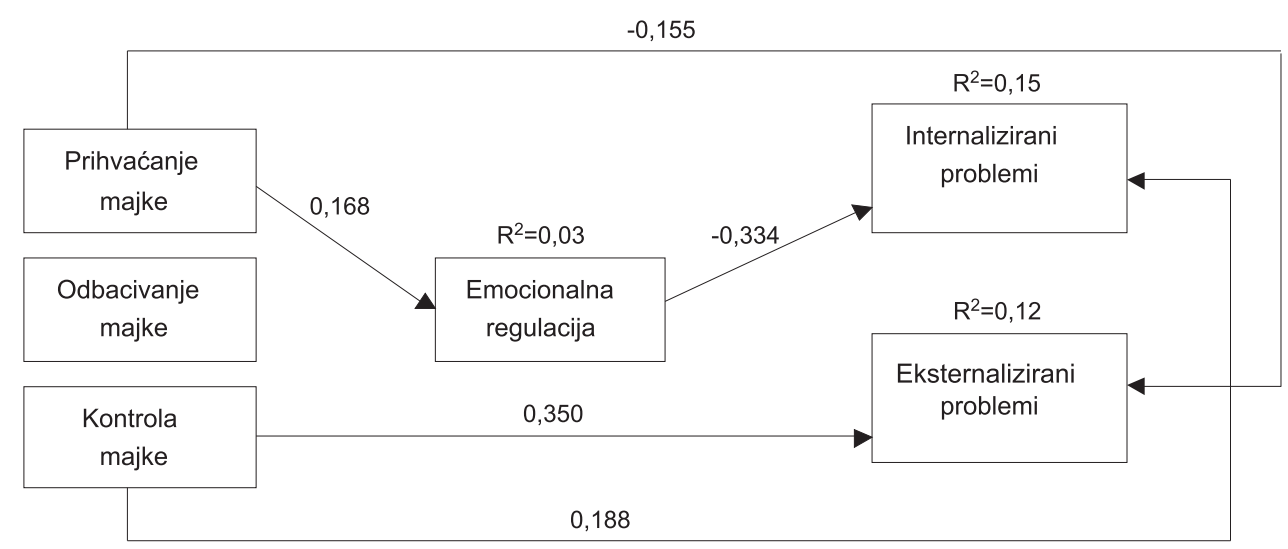




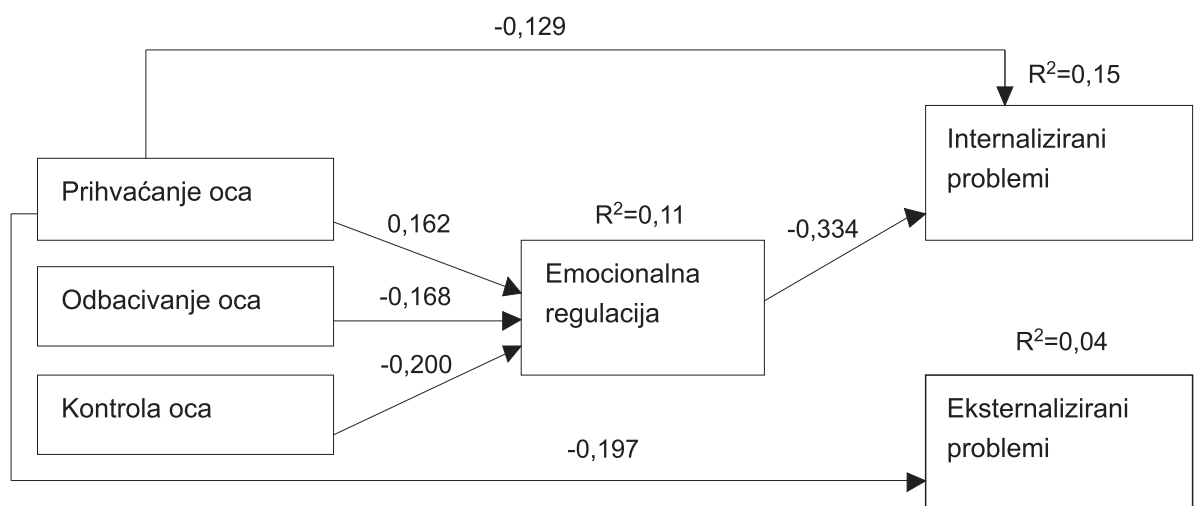

(1) SLIKA 2

Model odnosa roditeliskoga ponašanja očeva te emocionalne regulacije i dječjih internaliziranih $i$ eksternaliziranih problema
Zaključno, rezultati su pokazali da emocionalna regulacija posreduje u povezanosti između prediktorskih varijabli i internaliziranih problema, ali ne i eksternaliziranih problema. Specifičnije, procesi emocionalne regulacije potpuno su objasnili povezanosti između internaliziranih problema i dječje percepcije majčina prihvaćanja, očeva odbacivanja i kontrole, a djelomično i povezanost između internaliziranih problema i očeva prihvaćanja. Dječja percepcija majčine kontrole i očeva prihvaćanja imala je izravne učinke na internalizirane probleme, a eksternalizirani problemi bili su izravno povezani s dječjom percepcijom majčine kontrole te očeva i majčina prihvaćanja.

Cilj ovog istraživanja bio je provjeriti neke postavke Trostrukoga modela utjecaja obitelji na dječju emocionalnu regulaciju i prilagodbu autorice Morris i suradnika (2007.). Ovaj model predstavlja noviji pristup $u$ objašnjenju problema $u$ prilagodbi djece i adolescenata, s naglaskom na posredujućoj ulozi emocionalne regulacije $u$ odnosu između obiteljskoga funkcioniranja i dječje prilagodbe. U skladu s postavkama navedenoga modela, ovim istraživanjem provjerilo se utječe li zasebno roditeljsko ponašanje majki i očeva, osim izravno, i neizravno na dječju prilagodbu preko emocionalne regulacije. Kako autorica Morris i suradnici (2007.) navode, deficiti u sposobnostima emocionalne regulacije adolescenata predstavljaju ključan faktor rizika za razvoj internaliziranih i eksternaliziranih problema. Emocionalna regulacija utječe na prirodu emocionalnih iskustava i izraza, uključujući njihovu frekvenciju, intenzitet i trajanje, i može značajno sudjelovati u riziku za razvoj internaliziranih i eksternaliziranih simptoma. Osobito rana adolescencija predstavlja razdoblje povećanog rizika za pojavu problema internaliziranoga i eksternaliziranoga tipa zbog intenzivnih promjena na tjelesnom i psihosoci- 
DRUŠ. ISTRAŽ. ZAGREB GOD. 21 (2012)

BR. $2(116)$

STR. 383-403

MACUKA, I., SMOJVER-AŽIIĆ, S., BURIĆ, I. POSREDDUUUĆA. jalnom planu. Flannery i suradnici (1993.) navode da je u tom razdoblju jedna od značajnih promjena povećana učestalost i intenzitet negativnih emocija koje mogu prethoditi problemima. Zbog toga se činilo opravdanim uzeti mjeru emocionalne regulacije kojom se procjenjuje učinak neugodnih emocija i raspoloženja na mišljenje, pamćenje i ponašanje pojedinca. (Upitnik emocionalne regulacije i kontrole autora Takšića (2003.)). Autor navedene skale naglašava kako se inače sadržaj tvrdnji $\mathrm{u}$ raznim upitnicima emocionalne regulacije odnosi na emocionalnu inhibiciju i utjecaj negativnih emocija na mišljenje i ponašanje osobe. Dodatni je razlog što negativne emocije imaju znatniji utjecaj na mišljenje i ponašanje osobe, pa se problemi regulacije emocija najčešće javljaju kada se osoba ne može prilagoditi situaciji ili kontrolirati svoje negativne emocije. Iz toga se može pretpostaviti da uzrok problema zapravo odražava nemogućnost reguliranja negativnih emocija. Primjerice, dijete koje ne može regulirati svoj doživljaj straha često izbjegava određene situacije ili djeca koja su sklona depresivnim raspoloženjima neuspješno reguliraju svoj doživljaj tuge. Na temelju rezultata ovog istraživanja, može se zaključiti kako manje internaliziranih i eksternaliziranih problema imaju djeca koja bolje reguliraju svoje negativne emocije.

Utvrđena je značajna uloga roditeljskoga ponašanja očeva i majki u prilagodbi mlađih adolescenata. Odnosno, dječja percepcija majčine kontrole i očeva prihvaćanja imali su izravne učinke na internalizirane probleme, a eksternalizirani problemi bili su izravno povezani s percepcijom majčine kontrole te očeva i majčina prihvaćanja. Dobiveni rezultati potvrđuju pretpostavke o utjecaju roditeljskoga ponašanja na prilagodbu djece, djeca koja procjenjuju da im roditelji pružaju veću emocionalnu podršku, tj. prihvaćaju ih i podržavaju te pokazuju pozitivne emocije $\mathrm{u}$ odnosu, imaju manje internaliziranih i eksternaliziranih problema. Općenito, prihvaćanje ulazi u zasebnu dimenziju roditeljstva - emocionalnost i odnosi se na emocije koje roditelj doživljava i pokazuje u odnosu s djetetom te uključuje prihvaćanje, pružanje podrške, pokazivanje topline i pozitivnih emocija u odnosu s djetetom. Veća izraženost ove dimenzije roditeljskoga ponašanja povezana je s pozitivnim razvojnim ishodima kod djece, a manjak prihvaćanja i slaba podrška povezana je sa psihosocijalnim problemima kod djece (Cummings i sur., 2000.). Nadalje, kontrola majke, koja se $\mathrm{u}$ ovom istraživanju odnosi na negativnu psihološku kontrolu koja uključuje kontrolu djetetovih misli, manipuliranje djetetovim ponašanjem kritiziranjem, stvaranjem osjećaja krivnje te omalovažavanjem djetetovih osjećaja, predstavlja značajan rizičan faktor. Odnosno, djeca koja procjenjuju više razine takva oblika majčina kontroliranja imaju više razine internaliziranih i eksternaliziranih problema. U dru- 
DRUŠ. ISTRAŽ. ZAGREB GOD. 21 (2012), BR. 2 (116)

STR. $383-403$

MACUKA, I., SMOJVER-AŽIĆ, S., BURIĆ, I. POSREDUUJUCA. gim istraživanjima također se navode podaci koji se podudaraju s podacima dobivenim u ovom istraživanju o značajnom doprinosu psihološke kontrole djeteta od strane roditelja $u$ objašnjenju dječjih internaliziranih i eksternaliziranih problema (Barber, 1996.; Herman i sur., 1997.; Pettit i sur., 2001.; Stolz i sur., 2005.; Caron i sur., 2006.; Macuka, 2008.). Općenito, više razine roditeljske negativne kontrole, koja ne pogoduje razvoju nezavisnosti i individuacije, pridonosi dječjim problemima, a u ovom istraživanju utvrđen je značajan doprinos samo majčine kontrole dječjim internaliziranim i eksternaliziranim problemima.

Rezultati pokazuju kako se neki oblici roditeljskoga ponašanja majki i očeva mogu promatrati kao rizični faktori koji pridonose zastupljenosti internaliziranih i eksternaliziranih problema. Osobito se dječja percepcija majčine kontrole pokazala značajnim rizičnim faktorom te potvrđuje važnost percepcije vlastite autonomije $\mathrm{u}$ prilagodbi mlađih adolescenata. Kako period rane adolescencije obilježava intenzivno uspostavljanje neovisnoga psihološkog identiteta, čini se da je za uspješnu prilagodbu mlađih adolescenata podrška procesu individuacije vrlo važna. Iako se često $u$ istraživanjima roditeljskoga ponašanja ispituje uloga majke, u ovom istraživanju naglasak je bio i na analiziranju zasebnih doprinosa majčina i očeva roditeljskoga ponašanja. Ranija istraživanja zanemarivala su jedinstven i ponekad različit utjecaj majki i očeva na dječji razvoj (Stolz i sur., 2005.), a danas je očinstvo zaseban predmet istraživanja, pa se i shvaća kao neovisan i različit oblik roditeljstva od majčinstva. Nalazi ovog istraživanja potvrđuju važnu ulogu i roditeljskoga ponašanja očeva u dječjoj prilagodbi, odnosno internalizirani i eksternalizirani problemi bili su izravno povezani s percepcijom očeva prihvaćanja.

Osim izravnog utjecaja roditeljskoga ponašanja na dječju prilagodbu, provjerilo se posreduje li emocionalna regulacija u povezanosti roditeljskoga ponašanja i dječjih problema. Na osnovi analize traga, koja je pojednostavnjeni oblik strukturalnoga modeliranja, a rabi se kada se ispituje odnos među opaženim varijablama, provjerena je podudarnost pretpostavljenoga modela o emocionalnoj regulaciji u središtu dinamičnih odnosa između roditeljskoga ponašanja majki i očeva te dječje prilagodbe. Utvrđeno je da emocionalna regulacija potpuno objašnjava povezanost između internaliziranih problema i percepcije majčina prihvaćanja, očeva odbacivanja i kontrole, a djelomično i povezanost između internaliziranih problema i očeva prihvaćanja. Preciznije, dobiveni rezultati pokazuju da emocionalna regulacija djeluje kao medijator kojim neke dimenzije roditeljskoga ponašanja majki (prihvaćanje) i očeva (prihvaćanje, odbacivanje i kontrola) mogu pridonijeti razvoju internaliziranih problema kod djece $u$ ranoj adolescenciji. Međutim, nisu utvrđeni značajni indirektni efekti ana- 
DRUŠ. ISTRAŽ. ZAGREB GOD. 21 (2012)

BR. $2(116)$

STR. 383-403

MACUKA, I., SMOJVER-AŽIIĆ, S., BURIĆ, I. POSREDUUJUCA. liziranih varijabli preko emocionalne regulacije na dječje eksternalizirane probleme, što je vjerojatno odraz operacionalizacije konstrukta emocionalne regulacije. Odnosno, emocionalna se regulacija $u$ ovom istraživanju odnosi na procjene učinka neugodnih emocija i raspoloženja na mišljenje, pamćenje i ponašanje pojedinca. Ona uključuje evaluaciju vlastitih raspoloženja i može pokazivati koliko je osoba spremna posvetiti pažnju svojim negativnim osjećajima, što joj na kraju omogućuje da razumije vlastite emocije, obuzda ih i usmjeri tako da ne ometaju njezino funkcioniranje ili ispune očekivanja okoline. Djeca s internaliziranim problemima pokazuju više negativnih emocija i neadekvatnih načina reagiranja i vjerojatno češće evaluiraju vlastite negativne emocije, za razliku od djece sklone eksternaliziranim problemima, koja su često impulzivna i svojim ponašanjem stvaraju probleme drugima $\mathrm{u}$ okolini. Internalizirani problemi, koji su okrenuti prema unutra, češći su kod djece koja imaju problema u regulaciji vlastitih emocija, pa takva djeca često iskazuju depresivna raspoloženja, anksiozna su, povučena i zabrinuta. I u ovom istraživanju pokazalo se kako posredovanjem lošije emocionalne regulacije djeca iskazuju upravo više takvih internaliziranih problema.

Na temelju dobivenih rezultata može se zaključiti da ulogu roditelja ne treba zanemariti u ranoj adolescenciji jer dječja percepcija pojedinih dimenzija roditeljskoga ponašanja izravno utječe na prilagodbu, te neizravno uz posredovanje vještina emocionalne regulacije. Roditeljsko ponašanje zacijelo uključuje pozitivne i negativne emocije roditelja usmjerene prema djetetu. Kada djeca percipiraju da ih roditelji ne prihvaćaju, odbacuju i pretjerano kontroliraju i kritiziraju, ona su zbog doživljenih negativnih emocionalnih reakcija roditelja izložena češćim neugodnim emocijama i većem riziku da slabije reguliraju vlastite negativne emocije, ako su one učestale. Povećan nadzor djeteta koji nije u skladu s razvojnim statusom djeteta, a u periodu adolescencije potreba za autonomijom postaje izraženija, te sklonost roditelja izražavanju negativnih emocija prema djetetu zasigurno otežavaju uspješnu prilagodbu djece. Suprotno efektima odbacivanja i neprimjerene kontrole, djeca kojoj roditelji pružaju emocionalnu podršku imaju veće sposobnosti regulacije negativnih emocija i manje problema u prilagodbi.

$\mathrm{Na}$ kraju, korisno je spomenuti određena ograničenja ovog istraživanja. Treba istaknuti da su svi zaključci ovog istraživanja samo korelacijske prirode te da ne odražavaju uzročno-posljedične odnose među analiziranim pojavama. Stoga i rezultate provedene analize traga (kojima se testiraju kauzalne relacije među latentnim konstruktima) te njihovu interpretaciju treba shvatiti samo uvjetno. Naime, donošenje zaključaka o uzrocima nekih pojava ne omogućuje statistička meto- 
DRUŠ. ISTRAŽ. ZAGREB GOD. 21 (2012), BR. $2(116)$

STR. $383-403$

MACUKA, I., SMOJVER-AŽIĆ, S., BURIĆ, I. POSREDUUJUCA. da, nego provedba istraživanja s prikladnim nacrtom. S obzirom na korelacijsku prirodu istraživanja, ne mogu se isključiti ni obrnuti odnosi među varijablama, primjerice utjecaj karakteristika djeteta na roditeljsko ponašanje, što je i potvrđeno u nekim istraživanjima (Larsson i sur., 2008.). Stoga bi se buduća istraživanja mogla usmjeriti na druge istraživačke pristupe, poput križno-sekvencijalnoga nacrta s longitudinalnom komponentom, koji bi pružili valjanije informacije o smjeru utjecaja. Nadalje, istraživanje je provedeno na prigodnom uzorku učenika i kao takvo zacijelo u određenoj mjeri ograničuje mogućnost generalizacije dobivenih rezultata na čitavu populaciju djece rane adolescentne dobi. Naposljetku, s obzirom na to da je djetetov spol važan čimbenik u određivanju roditeljskoga ponašanja, u budućim istraživanjima bilo bi korisno pretpostavljene relacije među pojedinim konstruktima analizirati zasebno za dječake i djevojčice.

Istraživanja o posredujućoj ulozi emocionalne regulacije između osobnih i obiteljskih čimbenika te dječje psihosocijalne prilagodbe još uvijek nedostaju, jer se konstrukt emocionalne regulacije tek nedavno počeo intenzivnije istraživati, a to onemogućuje usporedbu dobivenih rezultata. Dobiveni podatak o emocionalnoj regulaciji kao mehanizmu kojim roditeljsko ponašanje majki i očeva ostvaruje učinke na internalizirane probleme podržava model Morrisove i suradnika (2007.), koji je poslužio kao teorijska okosnica ovog istraživanja. U okvirima hrvatske populacije vrlo se malo zna o poteškoćama $\mathrm{u}$ reguliranju negativnih emocija koje su povezane s internaliziranim i eksternaliziranim dječjim problemima, pa ovo istraživanje daje svojevrstan doprinos otkrivanju etioloških faktora dječjih problema. Dobiveni rezultati ovog istraživanja mogu biti korisne smjernice za daljnja istraživanja na ovom području. Teorijski model koji je upotrijebljen za postavljanje hipoteza uključuje razne osobne (dječje i roditeljske) i obiteljske zaštitne i rizične čimbenike, od kojih su se samo neki analizirali u ovom istraživanju, pa kao i svaki model, i ovaj očekuje daljnju empirijsku provjeru da bi se utvrdio kompleksan sustav odnosa činitelja koji pridonose psihosocijalnoj prilagodbi adolescenata.

\section{LITERATURA}

Achenbach, T. M., Becker, A., Dopfner, M., Heiervang, E., Roessner, V. i Steinhausen, H. C. (2008.), Multicultural Assessment of Child and Adolescent Psychopathology with ASEBA and SDQ Instruments: Research Findings, Applications, and Future Directions. Journal of Child Psychology and Psychiatry, 49 (3): 251-275. doi:10.1111/j.1469-7610.2007. 01867.x

Achenbach, T. M. i Rescorla, L. A. (2001.), Manual for the ASEBA School-Age Forms \& Profiles, Burlington, VT, University of Vermont, Research Center for Children, Youth \& Families. 
DRUŠ. ISTRAŽ. ZAGREB GOD. 21 (2012) BR. 2 (116),

STR. 383-403

MACUKA, I., SMOJVER-AŽIIĆ, S., BURIĆ, I. POSREDUJUĆA.
Archer, J. (2004.), Sex Differences in Aggression in Real-World Settings: A Meta-Analytic Review. Review of General Psychology, 8 (4): 291-322. doi:10.1037/1089-2680.8.4.291

Barber, B. K. (1996.), Parental Psychological Control: Revisiting a Neglected Construct. Child Development, 67 (6): 3296-3319. doi:10.2307/ 1131780

Brown, T. A. (2006.), Confirmatory Factor Analysis for Applied Research, New Jork, The Guilford Press.

Calkins, S. D., Smith, C. L., Gill, K. L. i Johnson, M. C. (1998.), Maternal Interactive Style across Contexts: Relations to Emotional, Behavioral, and Physiological Regulation during Toddlerhood. Social Development, 7 (3): 350-369. doi:10.1111/1467-9507.00072

Caron, A., Weiss, B., Harris, V. i Catron, T. (2006.), Parenting Behaviour Dimensions and Child Psychopathology: Specificity, Task Dependency, and Interactive Relations. Journal of Clinical Child and Adolescent Psychology, 35 (1): 34-45. doi:10.1207/s15374424jccp3501_4

Cicchetti, D., Ackerman, B. P. i Izard, C. E. (1995.), Emotions and Emotion Regulation in Developmental Psychopathology. Development and Psychopathology, 7 (1): 1-10. doi:10.1017/S0954579400006301

Cicchetti, D. i Toth, S. L. (1998.), The Development of Depression in Children and Adolescents. American Psychologist, 53 (2): 221-241. doi:10.1037/0003-066X.53.2.221

Cole, D. A., Tram, J. M., Martin, J. M., Homan, K. B., Ruiz, M. D. i Jacquez, F. M. (2002.), Individual Differences in the Emergence of Depressive Symptoms in Children and Adolescents: A Longitudinal Investigation of Parent and Child Reports. Journal of Abnormal Psychology, 111 (1): 156-165. doi:10.1037//0021-843X.111.1.156

Cole, P. M., Martin, S. E. i Dennis, T. A. (2004.), Emotion Regulation as a Scientific Construct: Methodological Challenges and Directions for Child Development Research. Child Development, 75 (2): 317-333. doi:10.1111/j.1467-8624.2004.00673.x

Cummings, E. M., Davies, P. T. i Campbell, S. B. (2000.), Developmental Psychopathology and Family Process: Theory, Research and Clinical Implications, New York, London, The Guilford Press.

Čudina-Obradović, M. i Obradović, J. (2006.), Psihologija braka i obitelji, Zagreb, Golden Marketing - Tehnička knjiga.

Darling, N. i Steinberg, L. (1993.), Parenting Style as Context: An Integrative Model. Psychological Bulletin, 113 (3): 487-496. doi:10.1037// 0033-2909.113.3.487

Eisenberg, N., Cumberland, A. i Spinrad, T. L. (1998.), Parental Socialization of Emotion. Psychological Inquiry, 9 (4): 241-273. doi:10.1207/ s15327965pli0904_1

Eisenberg, N., Cumberland, A., Spinrad, T. L., Fabes, R. A., Shepard, S. A. i Reiser, M. (2001.a), The Relations of Regulation and Emotionality to Children's Externalizing and Internalizing Problem Behavior. Child Development, 72 (4): 1112-1134. doi:10.1111/1467-8624.00337

Eisenberg, N., Fabes, R. A., Shepard, S. A., Guthrie, I. K., Murphy, B. C. i Reiser, M. (1999.), Parental Reactions to Children's Negative 
DRUŠ. ISTRAŽ. ZAGREB GOD. 21 (2012), BR. 2 (116)

STR. $383-403$

MACUKA, I., SMOJVER-AŽIĆ, S., BURIĆ, I. POSREDUUUJUCA
Emotions: Longitudinal Relations to Quality of Children's Social Functioning. Child Development, 70 (2): 513-534. doi:10.1111/1467-8624. 00037

Eisenberg, N., Losoya, S., Fabes, R. A., Guthrie, I. K., Reiser, M. i Murphy, B. (2001.b), Parental Socialization of Children's Dysregulated Expression of Emotion and Externalizing Problems. Journal of Family Psychology, 15 (2): 183-205. doi:10.1037//0893-3200.15.2.183

Eisenberg, N., Spinrad, T. L. i Morris, A. S. (2002.), Regulation, Resiliency, and Quality of Social Functioning. Self and Identity, 1 (2): 121-128. doi:10.1080/152988602317319294

Eisenberg, N., Zhou, Q., Spinrad, T. L., Valiente, C., Fabes, R. A. i Liew, J. (2005.), Relations among Positive Parenting, Children's Effortful Control, and Externalizing Problems: A Three-Wave Longitudinal Study. Child Development, 76 (5): 1055-1071. doi:10.1111/j.14678624.2005.00897.x

Flannery, D. J., Montemayor, R., Eberly, M. i Torquati, J. (1993.), Unraveling the Ties that Bind: Affective Expression and Perceived Conflict in Parent-Adolescent Interactions. Journal of Social and Personal Relationships, 10 (4): 495-509. doi:10.1177/0265407593104002

Gottman, J. M., Katz, L. F. i Hooven, C. (1996.), Parental Meta-Emotion Philosophy and the Emotional Life of Families: Theoretical Models and Preliminary Data. Journal of Family Psychology, 10 (3): 243-268. doi:10.1037//0893-3200.10.3.243

Gross, J. J. (1998.), The Emerging Field of Emotion Regulation: An Integrative Review. Review of General Psychology, 2 (3): 271-299. doi:10. 1037//1089-2680.2.3.271

Herman, M. R., Dornbuch, S. M., Herron, M. C. i Herting, J. R. (1997.). The Influence of Family Regulation, Connection, and Psychological Autonomy on Six Measures of Adolescent Functioning. Journal of Adolescent Research, 12 (1): 34-67. doi:10.1177/07435554897121004

Hu, L. i Bentler, P. M. (1999.), Cutoff Criteria for Fit Indexes in Covariance Structure Analysis: Conventional Criteria Versus New Alternatives. Structural Equation Modeling, 6 (1): 1-55. doi:10.1080/1070551 9909540118

Kliewer, W., Fearnow, M. D. i Miller, P. A. (1996.), Coping Socialization in Middle Childhood: Tests of Maternal and Paternal Influences. Child Development, 67 (5): 2339-2357. doi:10.1111/j.1467-8624.1996. tb01861.x

Larsson, H., Viding, H., Rijsdijk, E. i Plomin, F. V. (2008.), Relationships between Parental Negativity and Childhood Antisocial Behavior Over Time: A Bidirectional Effects Model in a Longitudinal Genetically Informative Design. Journal of Abnormal Child Psychology, 36 (5): 633-645. doi:10.1007/s10802-007-9151-2

Macuka, I. (2007.a), Skala percepcije roditeljskog ponašanja - procjena valjanosti. Suvremena psihologija, 10 (2): 179-199.

Macuka, I. (2007.b), Uloga determinanti roditeljskog ponašanja u objašnjenju internaliziranih i eksternaliziranih problema u djece, Magistarski rad, Zagreb, Filozofski fakultet, Sveučilište u Zagrebu. 
DRUŠ. ISTRAŽ. ZAGREB GOD. 21 (2012) BR. 2 (116),

STR. 383-403

MACUKA, I., SMOJVER-AŽIIĆ, S., BURIĆ, I. POSREDUJUĆA.
Macuka, I. (2008.), Uloga dječje percepcije roditeljskog ponašanja u objašnjenju internaliziranih i eksternaliziranih problema. Društvena istraživanja, 17 (6): 1179-1202.

Macuka, I. (2011.), Uloga obitelji $i$ emocionalne regulacije u prilagodbi mlađih adolescenata, Doktorski rad, Zagreb, Filozofski fakultet, Sveučilište u Zagrebu.

Martin, C. A. i Colbert, K. K. (1997.), Parenting - A Life Span Perspective, New York, McGraw-Hill.

Morris, A. S., Silk, J. S., Steinberg, L., Myers, S. S. i Robinson, L. R. (2007.), The Role of the Family Context in the Development of Emotion Regulation. Social Development, 16 (2): 361-388. doi:10.1111/j.14679507.2007.00389.x

Muthen, L. K. i Muthen, B. O. (2009.), Mplus User's Guide, Fifth Edition, Los Angeles, CA, Muthen \& Muthen.

Pettit, G. S., Laird, R. D., Dodge, K. A., Bates, J. E. i Criss, M. M. (2001.), Antecedents and Behavior-Problem Outcomes of Parental Monitoring and Psychological Control in Early Adolescence. Child Development, 72 (2): 583-598. doi:10.1111/1467-8624.00298

Riley, D. i Steinberg, J. (2004.), Four Popular Stereotypes about Children in Self-Care: Implications for Family Life Educators. Family Relations, 53 (1): 95-101. doi:10.1111/j.1741-3729.2004.00013.x

Shipman, K. L. i Zeman, J. (2001.), Socialization of Children's Emotion Regulation in Mother-Child Dyads: A Developmental Psychopathology Perspective. Development and Psychopathology, 13 (2): 317-336. doi:10.1017/S0954579401002073

Silk, J. S., Steinberg, L. i Morris, A. S. (2003.), Adolescents' Emotion Regulation in Daily Life: Links to Depressive Symptoms and Problem Behavior. Child Development, 74 (6): 1869-1880. doi:10.1046/j.1467-8624. 2003.00643.x

Steinberg, L. D. (2005.), Cognitive and Affective Development in Adolescence. Trends in Cognitive Sciences, 9 (2): 69-74. doi:10.1016/j.tics. 2004.12.005

Stolz, H. E., Barber, B. K. i Olsen, J. A. (2005.), Toward Disentangling Fathering and Mothering: An Assessment of Relative Importance. Journal of Marriage and Family, 67 (4): 1076-1092. doi:10.1111/j.1741-3737. 2005.00195.x

Takšić, V. (2003.), Skala emocionalne regulacije i kontrole (ERIK): provjera faktorske strukture. Psihologijske teme, 12 (1): 43-54.

Thompson, R. A. (1994.), Emotion Regulation: A Conceptual Theme in Search of Definition. U: N. A. Fox (ur.), The Development of Emotion Regulation: Biological and Behavioral Considerations (str. 25-52), Chicago, The University of Chicago Press.

Tram, J. M. i Cole, D. A. (2006.), A Multimethod Examination of the Stability of Depressive Symptoms in Childhood and Adolescence. Journal of Abnormal Psychology, 115 (4): 674-686. doi:10.1037/0021-843X. 115.4 .674 
DRUŠ. ISTRAŽ. ZAGREB GOD. 21 (2012), BR. 2 (116)

STR. $383-403$

MACUKA, I., SMOJVER-AŽIĆ, S., BURIĆ, I. POSRÉDUUJUĆA,

\section{Mediating Role of Emotional Regulation between Parental Behavior and Adjustment of Early Adolescents}

Ivana MACUKA

University of Zadar, Zadar

Sanja SMOJVER-AŽIĆ

Faculty of Arts and Science, Rijeka

Irena BURIĆ

University of Zadar, Zadar

The aim of this study was to examine the relationships between parental behavior of both parents, and emotional regulation and internalizing and externalizing problems of young adolescents. Specifically, the mediating role of emotional regulation in relation between parental behavior and adjustment of young adolescents, were tested. The study was conducted on a sample of 261 subjects (139 girls and 122 boys), average age of 13 years. Using path analysis, direct and indirect effects (via emotional regulation) of parental behavior on internalizing and externalizing problems were examined. The results indicate that emotional regulation fully mediated the associations between internalizing problems and children's perceptions of maternal acceptance, paternal rejection and control. Furthermore, emotional regulation partially mediated the relationship between internalizing problems and paternal acceptance. Children's perceptions of maternal control and paternal acceptance had direct effects on internalizing problems, and externalizing problems were directly related to perception of maternal control and acceptance, as well as paternal acceptance.

Keywords: emotional regulation, internalizing and externalizing problems, parental behavior, early adolescence 